\title{
COARSE BED SEDIMENTS IN A HEADWATER CHANNEL AS INDICATORS OF FLUVIAL PROCESSES AND SLOPE-CHANNEL COUPLING: A CASE STUDY FROM THE CARPATHIAN MOUNTAINS (CZECH REPUBLIC)
}

\author{
Tomáš GALIA, Václav ŠKARPICH
}

\begin{abstract}
The character of riverbed sediments usually reflects fluvial processes and the dynamics of sediment transport in fluvial systems. The approach in this study was based on the measurement of the largest boulders located within a bankfull channel, and on the observation of changes in their size in the longitudinal profile of a headwater stream in the Moravian-Silesian Beskids Mountains. The resulting trends in a particle-size index reflect the character of sediment delivery into channel segments and the recent channel-forming processes. The largest boulders were observed in channel sections with a strong interaction of slope and fluvial processes, and a slight coarsening of sediments was recorded in the incised downstream sections of the longitudinal stream profile. In contrast, the refining of bed sediments was typical of the transitional zone between slope-channel coupled reaches and an alluvial cone characterised by a tendency to material aggradation.
\end{abstract}

\section{Shrnutí}

\section{Hrubá sedimentární frakce pramenného toku jako indikátor fluviálních procesů a vazby mezi svahy a korytem: př́kladová studie z Karpatského pohoří (Česká republika)}

Charakter dnových sedimentů $v$ ríčních systémech obvykle odráží probíhající fluviální procesy a dynamiku transportu sedimentů. Naše metodika byla založena na měrení největších valounů a balvanů uvnitř aktivního koryta a sledování velikostních změn v rámci podélného profilu beskydského pramenného toku. Výsledné trendy indexu velikosti klastů reflektují charakter donášky sedimentů do korytových segmentů a současné korytotvorné procesy. Největší balvany byly pozorovány v korytových úsecích se silnou interakcí svahových a fluviálních procesů a mírné hrubnutí sedimentũ bylo pozorováno $v$ zahlubujicích se úsecích dolní části studovaného podélného profilu toku. Naopak zjemňování dnových sedimentů bylo typické pro přechodnou zónu mezi korytovými úseky prrimknutými ke svahům a úseky nacházejícími se na proluviálním kuželu, kde se spíše projevovala agradace materiálu.

Key words: headwater stream, bed sediments, fluvial processes, slope-channel coupling, MoravianSilesian Beskids Mountains, Czech Republic

\section{Introduction}

Steep headwater channels are understood as an integral part of the fluvial network connecting the mountain landscape with lowland streams. They also control sediment delivery into lowland channels with regard to its amount and nature (Chartrand, Whiting, 2000). This implies that the mountain streams function as an open system connecting hill slope and fluvial processes (Owczarek, 2008). Therefore, modern researchers discuss slope-channel coupling processes (e.g. Walling, 1983; Fryirs, Brierley, 1999; Smith, Dragowich, 2008; Fuller, Marden, 2011), or hillslope sediment delivery zones (Owczarek, 2008). The system dynamics are affected by several factors, including climate, the frequency of high-magnitude events such as floods or debris-flows, and the internal dynamics of adjacent slopes (Chiverrell et al., 2009). In addition, human intervention represented by changes in land cover, as well as by the construction of hydraulic structures in channels, affected channelslope interactions in the past. 
Coarse bed sediments play an important role in highgradient streams as they act as important dissipaters of flow energy affecting the potential sediment transport and erosion processes (Reid, Hickin, 2008). Downstream coarsening of bed sediments was observed in headwater mountain watersheds $\left(\mathrm{A}<10 \mathrm{~km}^{2}\right)$ with respect to continual sediment supply from adjacent hillslopes or scouring of debris-flows (Brummer, Montgomery, 2003; Wohl, Wilcox, 2005; Vianello, D'Agostino, 2007). Nevertheless, this trend may be disrupted by lithological characteristics of sediment inputs (Golden, Springer, 2006) or human intervention in the channels (Škarpich et al., 2010; Dade et al., 2011). Woody debris stored in the stream channels significantly affects the average size of bed particles, too (e.g. Kaczka, 2003; Montgomery et al., 2003), and it plays an important role in the development of stepped-bed morphologies (Gomi et al., 2003).

In other cases, the refining of bed sediments begins at points where slopes are disconnected from stream channels due to the initial occurrence of floodplain segments, and thus stepped-bed morphology is gradually transformed to plane beds and pool-riffles (Golden, Springer, 2006). The connectivity of coarse sediment flux in river systems was examined by the movement of forms (e.g. bars) or size populations of particles (e.g. cobbles) in gravel-bed channels, while great attention was paid to sediment delivery zones (Hooke, 2003; Hradecký, Děd, 2008; Owczarek, 2008). Other studies deal with variations in median grain sizes of bed sediments (Surian, 2002; Brummer, Montgomery, 2003; Attal and Lavé, 2006; Vianello and D'Agostino, 2007; Škarpich et al., 2010), or changes in the lithology of bed sediments due to sediment supply coming out from the tributaries (Attal, Lavé, 2006).

This paper presents a simple methodology to evaluate slope-channel coupling and fluvial processes in a headwater high-gradient stream of flysch midmountain relief (Moravian-Silesian Beskids Mts., Western Carpathians). Our approach is based on a detailed monitoring of the sizes of the largest boulders located in the bankfull channel and its comparison with the mapped zones of the potential sediment delivery, and observed erosion or depositional trends in the channel. Measuring diameters of a small number of the largest boulders in short steps (5 boulders at 10-m longitudinal distances in our case) represents a relatively less time-consuming, yet detailed method to obtain grain-size trends in the coarsest fraction of bed sediments along the longitudinal stream profile, when compared to classic pebble counts (in sensu Wolman, 1954). A cluster analysis verified the correlation between the sizes of the coarsest bed sediments, forms of sediment supply and prevailing processes in the channel-reaches under study.

\section{The case study watershed}

The study focused on the uppermost part of the Lubina River watershed, covering the northern slopes of the Radhoštská hornatina Mts., one of the culmination parts of the Moravian-Silesian Beskids Mts. In cross-sections investigated upstream, the watershed areas ranged between $0.20-1.11 \mathrm{~km}^{2}$ with regard to the beginning and the end of the studied stream longitudinal profile. Watershed altitudes vary between $990 \mathrm{~m}$ a.s.l. on ridges and $490 \mathrm{~m}$ a.s.l. at the end of the longitudinal profile. From the geological point of view, the watershed is built by the Cretaceous flysch nappe structure with alternating sandstones and claystones of different permeability, resulting in both shallow and deep landslide activity (Pánek et al., 2009, 2010, 2011). The highest parts of the watershed consist of massive Godula sandstones and, to a small extent, Ostravice sandstones, followed by predominantly claystone members in the lowest parts: Mazák Member, Lhoty Formation, Veřovice Member and the uppermost part of the Těšín-Hradiště Formation (Menčík, Tyráček, 1985). As illustrated in Fig. 1, the main channel of the stream under study begins in members with dominant claystone lithology. Thus in the first step, resistant sandstones of the Godula Member are transported into initial channelreaches from the uppermost parts of the watershed by hill slope processes.

A detailed analysis was performed on a $1.03-\mathrm{km}$-long reach of the profile, which belongs to the Trojanovická brázda Furrow in a geomorphological sense. This reach is underlain mainly by claystone bedrock of the Veřovice Member and the Těšín-Hradiště Formation. The end point of the 1.03-km-long reach was established near the outfalls of two left tributaries (Fig. 1). This location was selected because of a possible sediment delivery of Godula sandstones from the tributaries to the main channel, and the presence of artificial bank stabilization structures. The studied longitudinal profile was not affected by recent human impact except at the $0.43 \mathrm{~km}$ point, where some remains of a former small dam were found. The upper part of the Lubina River watershed represents a typical transitional area between steep mountain slopes with mean hill slope gradients of up to $40^{\circ}$ and a forefield area with significantly lower gradients of about $5^{\circ}$, which results in a variety of slope and fluvial processes. Generally, the sediment delivery from adjacent steep slopes prevails between 0.0 and $0.4 \mathrm{~km}$. The channel-reaches exhibit a tendency towards 
incision. Moreover, immediately upstream from the $0.0 \mathrm{~km}$ point, a sluice acts as a barrier to sediment transport during high-magnitude floods, playing an important role in such an accelerated erosion trend. Downstream from the $0.4 \mathrm{~km}$ point, sediment inputs are mostly represented by bank failures developed in alluvial and proluvial sediment cover. Except for the prevailing erosion trends occurring due to elementary functions of mountain headwater channels, significant aggradation is identified in some reaches between 0.4 and $0.8 \mathrm{~km}$, which are also affected by small woody debris jams. On the other hand, deeplyincised channel-reaches in an alluvial fan are located downstream from the $0.8 \mathrm{~km}$ point (Fig. 2).

Annual precipitation in the case study watershed is $1,240 \mathrm{~mm}$ according to the 1954-2005 data series coming from the Malá Ráztoka experimental watershed located in the Radhoštská hornatina Mts. During extreme flood events, specific discharges may reach up to $2000-3000 \mathrm{l} \cdot \mathrm{s}^{-1} \cdot \mathrm{km}^{-2}$ (Bíba et al., 2006). The evaluation of bed-load transport in

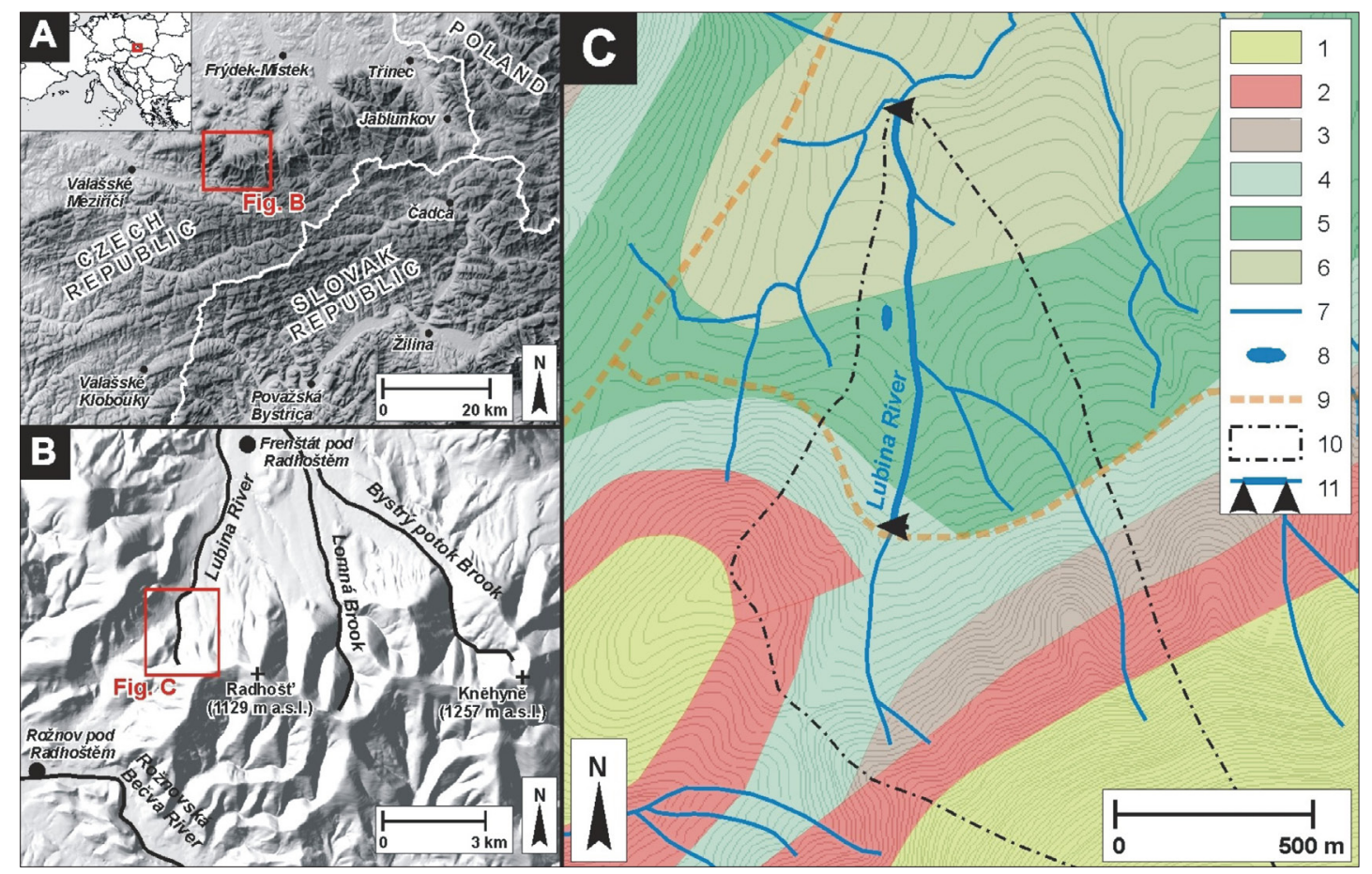

Fig. 1: Study area (Geological conditions: 1-Godula Formation, 2-Ostravice sandstones, 3-Mazák Member, 4-Lhoty Formation, 5-Veřovice Member, 6-Těšín-Hradiště Formation, 7-stream, 8-reservoir, 9-road, 10 - boundaries of the study watershed, 11 - beginning and end of the longitudinal profile)

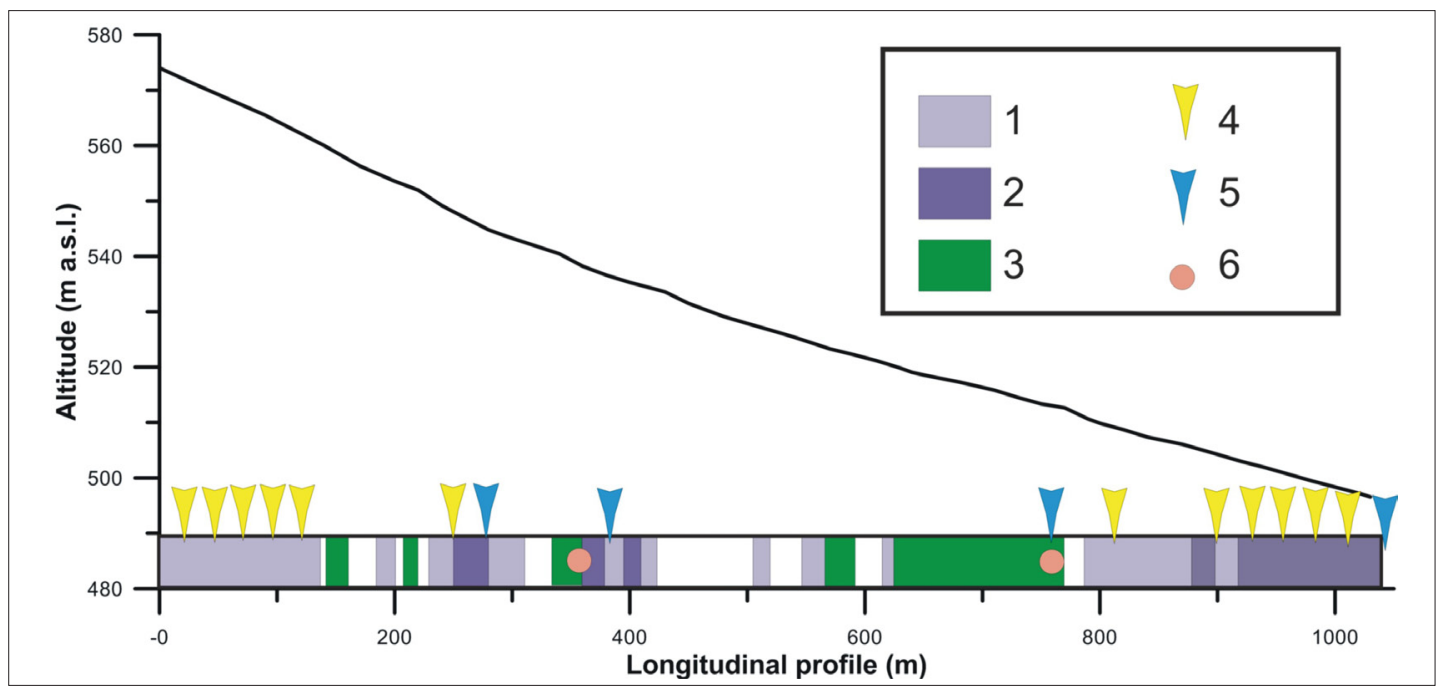

Fig. 2: Scheme of the study longitudinal profile of the Lubina stream; 1 -erosion trends with incision $\leq 0.5 \mathrm{~m}$, 2 - erosion trends with incision $>0.5 \mathrm{~m}, 3$ - aggradation trends, 4 - bank failure, 5 - tributary, 6 - woody debris jam 
some upper channel-reaches (c. $0.0-0.5 \mathrm{~km}$ of the studied longitudinal profile) clearly demonstrated that a $Q_{20}$ high-magnitude flood event was able to transport almost all bed material in local headwater channels. After the event, large boulders with diameters of up to $0.3-0.4 \mathrm{~m}$ were found in post-flood accumulations (Galia, Hradecký, 2011; 2012). Forest cover in the studied area is close to $100 \%$, but the socalled Wallachian colonisation resulted in extensive deforestation of the Moravian-Silesian Beskids Mts. during the $16-17^{\text {th }}$ centuries, and then later reforestation at the turn of the $19^{\text {th }}$ and $20^{\text {th }}$ centuries. The recent forest cover consists of spruce and beech in the upper part of the watershed, while beech is considered to be a dominant species along the studied longitudinal profile.

\section{Methods}

The fluvial-geomorphic mapping provided detailed information on recent channel-forming processes of selected headwater parts of the Lubina stream. Sediment inputs such as hill slope debris scours, bank failures and small tributaries were recorded in the schematized longitudinal profile of the stream with respect to their potential sediment delivery into channel segments. Channel-reaches with trends of recent incision, balance and aggradation were distinguished as representing general stream behaviour under recent local conditions. Incised reaches were later divided into deeply-incised segments $(>0.5 \mathrm{~m})$ and segments displaying minor erosion trends $(\leq 0.5 \mathrm{~m})$. Moreover, positions of large woody debris or small woody debris jams were recorded because of their influence on the grain-size distribution and sediment transport.

All three axes (dimensions) of the five largest boulders were measured at $10 \pm 1 \mathrm{~m}$ intervals of the longitudinal profile except for the $0.44 \mathrm{~km}$ point, where the remains of a former dam occur. The measured boulders were mostly found within the bankfull channel; boulders buried in flood accumulations or situated on adjacent hill slopes above the bankfull depth were omitted from further analysis. A total of 515 boulders were evaluated in 103 channel cross-sections between the 0.0 and $1.03 \mathrm{~km}$ points. Average grain diameter and particle-size index based on the nominal diameter $D_{n}=(a . b . c)^{1 / 3}$ were computed for a single channel cross-section, in fact representing grain-size percentiles $d_{95}-d_{99}$ of bed material. All measured boulders were sandstones of the Godula Member that do not occur in the evaluated longitudinal profile as underlying bedrock. This implies that sandstone boulders were first transported by slope processes into initial channels from the uppermost parts of the watershed. This resulted in a bi-modal character of bed sediments in the studied stream. The ratio of resistant sandstone particles usually varied between 55-70\% of total pebble counts. Debris flow activity was not identified in the studied watershed.

Bankfull channel geometry was obtained in c. 50-m intervals. Efforts were made to collect data in positions which were not greatly influenced by unusual elements, such as the presence of large woody debris or large bank failures, in order to achieve a general trend of the progress of bankfull parameters. Laser rangefinder and clinometer were used to measure the mean channel gradient for relatively homogenous channel-reaches, the lengths of which usually varied from 10 to 30 meters.

Statistical testing (the Mann-Whitney U test) was applied to reveal significant differences between the coarse bed sediments of the individual sections of the longitudinal profile. Cluster analysis based on the K-means algorithm was conducted to group some samples of the evaluated channel cross-sections. The calculations comprised the values of the particlesize index in the cross-sections and distances of the cross-sections from the beginning of the studied longitudinal profile.

\section{Results}

The average grain diameter based on the measurement of the $b$-axis and the particle-size index $D_{n}$ from the evaluation of all three axes of a particle, exhibit a strong correlation $\left(R^{2}=0.86\right)$ expressed by the linear trend: $D_{n}=0.77 \mathrm{~b}+1.14$, where $b$ is the mean length (m) of the middle axis of the five largest boulders. Later in the study, $D_{n}$ is used to represent mean values of this index for the five largest boulders in a single evaluated channel cross-section.

Variations in the particle-size index, channel gradient and hydraulic radius within the longitudinal profile are demonstrated in Fig. 3. Proportionality between the channel gradient $\mathrm{S}$ and grain size is not significant, even though a weak relationship $\left(R^{2}=0.26\right)$ exists in the resulting linear trend: $D_{n}=77.6 \mathrm{~S}+12.1$. No relationship occurs between the particle-size index and bankfull geometry, represented by channel width, depth or hydraulic radius $\left(0.00<\mathrm{R}^{2}<0.01\right)$. On the other hand, Fig. 3 displays a clear trend of sediment refining within the longitudinal profile. The linear relationship takes the following form: $D_{n}=-8.73 \mathrm{~L}+27.18\left(\mathrm{R}^{2}=0.53\right)$, where the channel length $\mathrm{L}(\mathrm{km})$ is defined as distance from the source of the stream. Plotting drainage area $\mathrm{A}\left(\mathrm{km}^{2}\right)$ instead of channel length shows a slightly lower dependence $\left(\mathrm{R}^{2}=0.47\right)$ expressed as $D_{n}=-6.71 \mathrm{~A}+22.5$. 


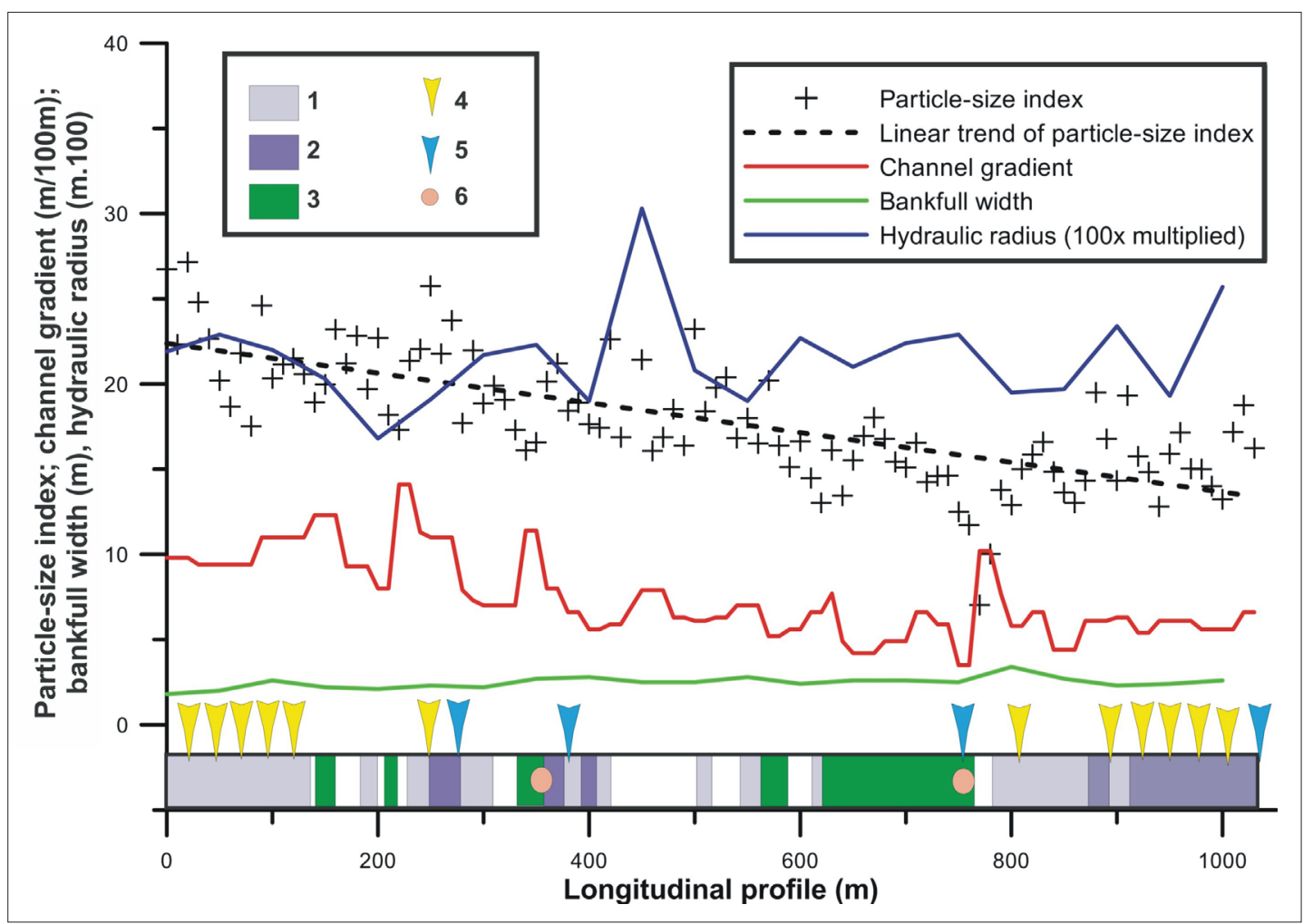

Fig. 3: Variations in the particle-size index, channel gradient and hydraulic radius within the longitudinal profile 1 - erosion trends with incision $\leq 0.5 \mathrm{~m}, 2$ - erosion trends with incision $>0.5 \mathrm{~m}, 3$-aggradation trends, $4-$ bank failure, 5 - tributary, 6 -woody debris jam

The longitudinal profile was later divided into three relatively homogenous sections with respect to sediment delivery and prevailing fluvial processes (Fig. 4). The uppermost section A $(0.00-0.37 \mathrm{~km})$ represents a channel - slope coupled system in which coarse material is predominantly delivered from adjacent steep hill slopes. We assume that the intensity of such sediment delivery decreases downstream with the decreasing gradient of adjacent hill slopes. The erosive character of the section is documented by the presence of an incised gully shape of the valley, including a number of bank failures. This phenomenon resulted in significantly higher values of the particle-size index than in the other two sections, as statistically demonstrated by the Mann-Whitney U test statistic $(\mathrm{p}<0.001)$. Only a weak relationship exists between the channel length and the particle-size index corresponding to downstream sediment refining $\left(\mathrm{R}^{2}=0.22\right): D_{n}=-11.41 \mathrm{~L}+29.37$.

The subsequent section B $(0.37-0.79 \mathrm{~km})$ generally lacks the sediment delivery of material from adjacent hill slopes, whereas the channel segment is supplied mostly with coarse material from fan deposits. Upper parts of the section are characterised by a balance between erosion and deposition, with a small number of incised channel-reaches. On the contrary, the reaches between the $0.55-0.75 \mathrm{~km}$ often contain large gravel deposits within the channel and these reaches can be understood as recently transport-limited. The downstream refining of coarse bed material is significant for the entire longitudinal profile of section B $\left(\mathrm{R}^{2}=0.53\right): D_{n}=-18.5 \mathrm{~L}+37.48$. Grainsize analysis showed no effect of the former small dam (at $0.44 \mathrm{~km}$ ) on bed sediments. Therefore, remaining parts of the dam can hardly be considered as a recent barrier to coarse sediment flux.

Section C (0.79-1.03 km), as the most downstream part of the longitudinal profile, differs significantly since the channel incises approximately 1-2.5 meters into the valley bottom sediments. Sediment inputs come from bank failures cutting the coarse-grained matrix of fan deposits, inducing a weak tendency towards bed sediment coarsening $\left(\mathrm{R}^{2}=0.06\right): D_{n}=6.53 \mathrm{~L}+5.89$. Values of the particle-size index differ statistically between sections $B$ and $C(p=0.0097)$, depending on the presence of coarser sediments in section C.

Technically speaking, significant refining of bed sediments takes place through the $\mathrm{A}$ and $\mathrm{B}$ sections up to c. $0.8 \mathrm{~km}$, where this tendency passes to slight coarsening due to the occurrence of the deeplyincised reaches of the $\mathrm{C}$ section supplied with coarsegrained material. From the perspective of channelforming processes and the character of sediment supply, boundaries between the individual sections are not sharp. The discriminating cross-sections 


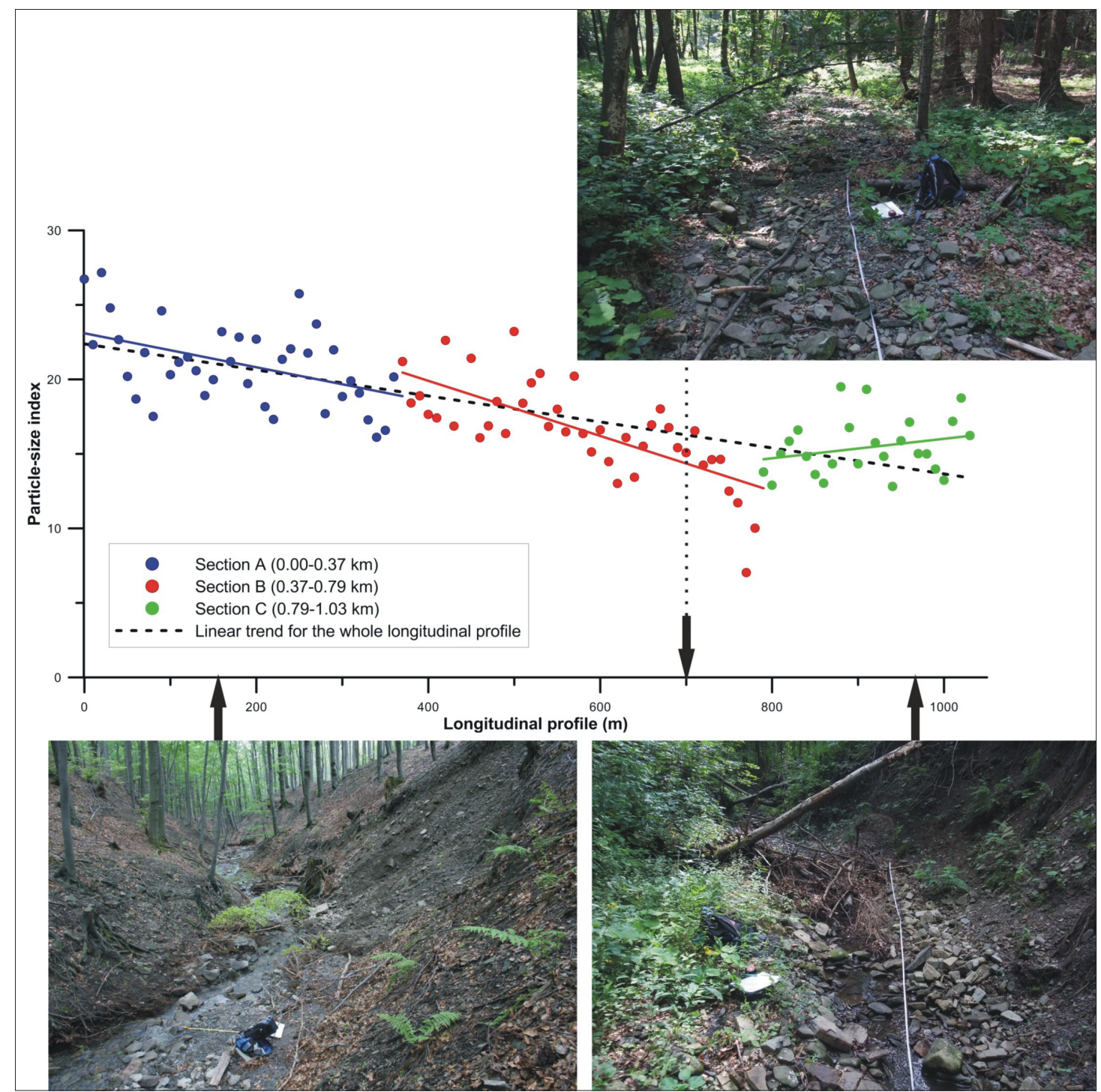

Fig. 4: Resulting trends in the particle-size index within the individual sections of the longitudinal profile; the photographs illustrate channel-reaches typical of the sections

(at 0.37 and $0.79 \mathrm{~km}$ ) were selected as "middle positions" points in the transitional zones between the prevailing processes. On the contrary, the expected fluvial transport of coarse sediments during high-magnitude floods (e.g. those in 1996, 1997, 2009 and 2010) did not erase differences in grain sizes and trends within the individual sections. This implies that bed-load transport in each section strictly relates to local stream power, and that dis-connectivity in the transport of coarse sediments may exist between the sections. Moreover, active sediment supply takes place in relation to the adjacent landforms, i.e. sediment inputs are triggered from steep hill slopes in section A or from coarse fan deposits in section $\mathrm{C}$ during high-magnitude events. In contrast, no influence of the larger right tributary was observed at the $0.35 \mathrm{~km}$ point on sizes of the largest boulders, despite the fact that the tributary acts as an important sediment input of Godula sandstone particles for the main channel.
Cluster analysis was used to determine whether a natural grouping existed on the basis of the obtained values of the particle-size index in relation to fluvial processes and sediment supply within the examined longitudinal profile. The best results were achieved by a grouping into six clusters (K1-K6) by the K-Means algorithm (Fig. 5). The K1 and K2 clusters correspond to the A section with high sediment delivery from the adjacent hill slopes. Moreover, the highest values of the particle-size index included in the $\mathrm{K} 1$ cluster may have underlined the incision trends due to the upstream presence of a sluice acting as a barrier in the sediment flux, and the related effect of "hungry water" in this channel-reach (c. $0.00-0.05 \mathrm{~km}$ ). The $\mathrm{K} 3$ cluster represents a transition zone between the hill slope delivery of the A section and some transport-balanced or incised cross-sections of the B section. The transport-balanced trend with an inclination towards aggradation is included in the K4 cluster, typical of downstream parts of 


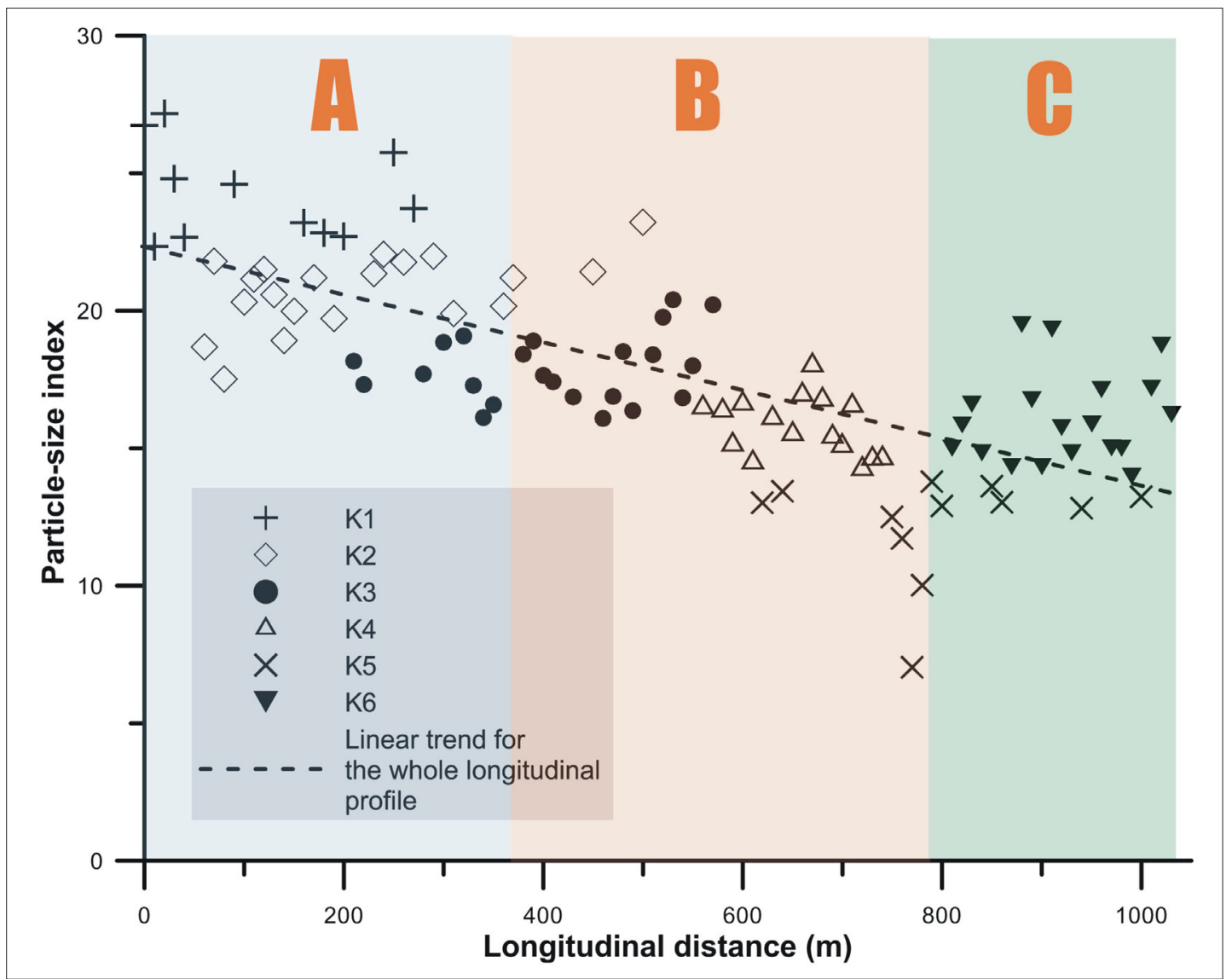

Fig. 5: Grouping of individual channel cross-sections on the basis of a K-means cluster analysis, with the positions of individual sections

the B section. The K5 cluster represents the finest bed sediment connected, in most cases, with the tendency towards aggradation due to the presence of large woody debris or woody jams in the bankfull channel of the transitional zone between the $\mathrm{B}$ and $\mathrm{C}$ sections. Finally, the K6 cluster strictly delineates the deeply incised channel-reaches of the $\mathrm{C}$ section. The coarse character of the bed material derives from the intensive erosion of deposits of the alluvial cone in these channel-reaches.

\section{Discussion}

The trend of downstream bed material coarsening in small headwater channels (Brummer and Montgomery, 2003; Vianello, D’Agostino, 2007) was not confirmed in the studied part of the longitudinal profile for the coarsest fraction. The reported correspondence between the longitudinal stream distance from the source or the increase in the watershed area and the coarsest bed sediments, represented by the mean value of the particle-size index of the largest boulders, reflected:

a) changes in the lithology of the source bedrock, as the generally coarser resistant sandstones of the Godula Member are gradually substituted by finer particles of claystone members; and b) the role of slope-channel (de)coupling processes related to the intensity and nature of sediment supply. Thus, we can speculate that bed surface organization in the studied profile is responsive to the nature of bedrock lithology and channelshaping processes. In spite of its calculated weak correlation, the parameter of channel gradient also plays a certain role. This finding is in accordance with Golden and Springer (2006) and Hradecký and Děd (2008), who claim that the median grain size is not a function of the watershed area in small mountain headwater watersheds, namely due to the lithological nature of supplied sediments, the variety of sediment inputs in the longitudinal profile and the limited possibilities of sediment sorting in highly confined channels with small storage capacities.

Vianello and D'Agostino (2007) observed a significant power trend between the channel gradient and the size of bed sediments $\left(d_{50}, d_{90}\right)$ in an Alpine torrent. The same authors also documented a good relation between the bankfull width and the size of bed sediments, while the parameter of channel width was mainly dependent on change in watershed area. In contrast, bankfull geometry was recognized as an important independent variable for the size of the largest boulders within the 
Lubina River longitudinal profile. The observed range of bankfull widths (1.9-3.4 m) resulted from a variety of channel-forming processes rather than from the direct impact of an increase in drainage areas, and thus channel-forming discharges above the individual cross-sections $\left(0.20-1.11 \mathrm{~km}^{2}\right)$.

The recorded sizes of the largest boulders correctly reflected the prevailing erosion or depositional trends in the channel and forms of sediment inputs, despite the fact that we expected bed-load transport of coarse material during the recent flood events. Even the automated cluster analysis performed on the basis of particle-size index and channel length was able to distinguish channel-reaches from the perspective of their recent behaviour and sediment supply conditions. Hooke (2003) reported a potentially limited connectivity for coarse sediments in the fluvial system with respect to stream power during floods. A highmagnitude flood $\left(\mathrm{Q}_{20}\right)$ was able to move boulders of up to $0.4 \mathrm{~m}$ in diameter in some upstream channelreaches (Galia, Hradecký, 2011, 2012). Connectivity in the bed-load transport of this sediment-size fraction is interrupted in downstream parts due to the decreased channel gradient, the presence of a larger space for the deposition of material between the channel and valley slopes, and a more frequent occurrence of woody debris in the channel. In addition, the incision trends are imprinted in the coarsening of bed material in the $\mathrm{C}$-section. That is in line with the observation of Škarpich et al. (2010), who documented bed material coarsening in the incised reaches of torrents in the Moravian-Silesian Beskids Mts. Moreover, relatively many authors discuss a linkage between the incised channels and the coarsening of bed sediments in gravelbed rivers (e.g. Wyżga, 1993; Kondolf, 1997; Škarpich et al., 2012). Similarly, Owczarek (2008) identified alluvial bars characterised by angular coarse material, which are strictly related to hill slope sediment delivery zones.

\section{Conclusion}

The evaluation of the largest boulders in a bankfull channel revealed significant trends in stream behaviour and the nature of sediment supply in the longitudinal profile of a mountain headwater stream. The role of slope processes was accentuated by the presence of uniform sandstone lithology of the studied bed particles. This simple method, based on the measurement of the largest boulders in connected cross-sections (five boulders at $10 \mathrm{~m}$ intervals, in our case), can be used as a demonstration of the assessment of channel-forming processes, as well as in the observation of (dis)connectivity in coarse sediment transport.

Nevertheless, this approach needs to be tested and verified in a variety of headwater channels, e.g. in torrents impacted by human actions, in high-gradient streams influenced by debris-flow scouring, or in streams with different geological conditions.

\section{Acknowledgement}

This research project was supported by the University of Ostrava foundation: SGS4/PrF/2012. The authors would like to thank sincerely Zdeněk Máčka and an anonymous reviewer, whose comments significantly contributed to the improvement of the manuscript. Thanks are extended also to Monika Hradecká for review of the English text.

\section{References:}

ATTAL, M, LAVÉ, J. (2006): Changes of bedload characteristics along the Marsyandi River (central Nepal): Implications for understanding hillslope sediment supply, sediment load evolution along fluvial networks, and denudation in active orogenic belts. In: Willett, S. D., Hovius, N., Brandon, M. T. and Fisher, D. M. [eds.]: Tectonics, Climate, and Landscape Evolution: GSA Special Papers. Vol. 398, p. 143-171.

BÍBA, M., OCEÁNSKÁ, Z., VÍCHA, Z., JAŘABAČ, M. (2006): Lesnicko-hydrologický výzkum v beskydských experimentálních povodích. Journal of hydrology and hydromechanics, Vol. 54, No. 2, p. 113-122.

BRUMMER, C. J., MONTGOMERY, D. R. (2003): Downstream coarsening in headwater channels. Water Resources Research, Vol. 39, No. 10, p. 1-14.

CHARTRAND, S. M., WHITING, P. J. (2000): Alluvial architecture in the headwater streams with special emphasis on steppool topografy. Earth Surface Process and Landforms, Vol. 25, p. 583-600.

CHIVERRELL, R. C., FOSTER, G. C., MARSHALL, P., HARVEY, A. M., THOMAS, G. S. P. (2009): Coupling relationships: Hillslope-fluvial linkages in the Hodder catchment, NW England. Geomorphology, Vol. 109, p. 222-235.

DADE, W. B., RENSHAW, C. E., MAGILLIGAN, F. J. (2011): Sediment transport constraints on river response to regulation. Geomorphology, Vol. 126, p. 245-251.

FRYIRS, K. BRIERLEY, G. J. (1999): Slope channel decoupling in Wolumla catchment, South Coast, New South Wales, Australia: the changing nature of sediment sources since European settlement. Catena, Vol. 35, p. 41-63. 
FULLER, I. C., MARDEN, M. (2011): Slope-channel coupling in steepland terrain: A field-based conceptual model from the Tarndale gully and fan, Waipaoa catchment, New Zealand. Geomorphology, Vol. 128, p. 105-115.

GALIA, T., HRADECKÝ, J. (2011): Bedload transport and morphological effects of high-magnitude floods in small headwater streams - Moravskoslezské Beskydy Mts. (Czech Republic). Journal of hydrology and hydromechanics, Vol. 59, No. 4, p. 238-250.

GALIA, T., HRADECKÝ, J. (2012): Critical conditions for beginning of coarse sediment transport in torrents of Moravskoslezské Beskydy Mts. (Western Carpathians). Carpathian journal of Earth and environmental sciences, Vol. 7, No. 4, p. 5-14.

GOLDEN, A. R., SPRINGER, G. S. (2006): Hydraulic geometry, median grain size, and stream power in small mountain streams. Geomorphology, Vol. 78, p. 64-76.

GOMI, T., SIDLE, R. C., WOODSMITH, R. D., BRYANT, M. D. (2003): Characteristics of channel steps and reach morphology in headwater streams, southeast Alaska. Geomorphology, Vol. 51, p. 225-242.

HOOKE, J. M. (2003): Coarse sediment connectivity in river channel systems: a conceptual framework and methodology. Geomorphology, Vol. 56, p. 79-94.

HRADECKÝ, J., DĚD, M. (2008): Současné trendy v zrnitostním složení sedimentů štěrkových lavic toků Moravskoslezských Beskyd - příkladová studie Sihelský potok. Geologické výzkumy na Moravě a ve Slezsku v roce 2007, p. 19-23.

KACZKA, R. J. (2003): Coarse woody debris dams in mountains streams in Central Europe, structure and distribution. Studia Geomorphologica Carpatho - Balcanica, Vol. 37, p. 111-127.

KONDOLF, G. M. (1997): Hungry water: effects of dams and gravel mining on river channels. Environmental Management, Vol. 21, p. 533-551.

MENČÍK, E., TYRÁČEK, J. (1985): Beskydy a Podbeskydská pahorkatina (Přehledná geologická mapa 1:100 000). Ústřední ústav geologický, Praha.

MONTGOMERY, D. R., COLLINS, B. D., BUFFINGTON, J. M., ABBE, T. B. (2003): Geomorphic effects of wood in rivers. In: Gregory, S., Boyer, K., Gurnell, A. M. [eds.]: The Ecology and Management of Wood in World Rivers, p. 21-47. American Fisheries Society Symposium 37.

OWCZAREK, P. (2008): Hillslope deposits in gravel-bed revers and their effects on the evolution of alluvial channel forms: A case study from the Sudetes and Carpathian Mountains. Geomorphology, Vol. 98, p. 111-125.

PÁNEK T., HRADECKÝ J., ŠILHÁN, K. (2009): Geomorphic evidence of ancient catastrophic flow type landslides in the mid-mountain ridges of the Western Flysch Carpathian Mountains (Czech Republic). International Journal of Sediment Research, Vol. 24, p. 88-98.

PÁNEK, T., HRADECKÝ, J., MINÁR, J., ŠILHÁN, K. (2010): Recurrent landslides predisposed by fault-induced weathering of flysch in the Western Carpathians. In: Calcaterra, D., Parise, M. [eds.]: Weathering as a Predisposing Factor to Slope Movements. 248 pp.

PÁNEK, T., TÁBOŘÍK, P., KLIMEŠ, J., KOMÁRKOVÁ, V., HRADECKÝ, J., ŠŤASTNÝ, M. (2011): Deep-seated gravitational slope deformations in the highest parts of the Czech Flysch Carpathians: Evolutionary model based on kinematic analysis, electrical imaging and trenching. Geomorphology, Vol. 129, p. 92-112.

REID, D. E., HICKIN, E. J. (2008): Flow resistance in steep mountain streams. Earth Surf. Process. Landforms, Vol. 33, p. 2211-2240.

SMITH, H. G., DRAGOVICH, D. (2008): Sediment budget analysis of slope-channel coupling and in-channel sediment storage in an upland catchment, southeastern Australia. Geomorphology, Vol. 101, p. 643-654.

SURIAN, N. (2002): Downstream variation in grain size along an Alpine river: analysis of controls and processes. Geomorphology, Vol. 43, p. 137-149.

ŠKARPICH, V., GALIA, T., HRADECKÝ, J., PEČ, J. (2010): Identifikace (dis)konektivit vodních toků za využití makrogranulometrické analýzy korytových sedimentů (Moravskoslezské Beskydy). Geologické výzkumy na Moravě a ve Slezsku v roce 2010, p. 199-204.

ŠKARPICH, V., GALIA, T., HRADECKÝ, J. (2012): Podmínky akumulace a transportu sedimentů v člověkem ovlivněných korytech Beskydských toků: př́kladová studie soutoku řeky Morávky a Mohelnice. Geologické výzkumy na Moravě a ve Slezsku v roce 2012, p. 53-58.

VIANELLO, A., D’AGOSTINO, V. (2007): Bankfull width and morphological units in an Alpine stream of the Dolomites (Northern Italy). Geomorphology, Vol. 83, p. 266-281.

WALLING, D. E. (1983): The sediment delivery problem. Journal of Hydrology, Vol. 65, p. 209-237. 
WOHL E. E., WILCOX, A. (2005): Channel geometry of mountain rivers in New Zealand. Journal of Hydrology, Vol. 300, p. $252-266$.

WOLMAN, M. G. (1954): A method of sampling coarse river-bed material. Transactions American Geophysical Union, Vol. 35, No. 6, p. 951-956.

WYŻGA, B. (1993): River response to channel regulation: Case study of the Baba River, Carpathians, Poland. Earth surface processes and landforms, Vol. 18, p. 541-556.

\section{Authors' addresses:}

RNDr. Tomáš GALIA, Ph.D., email: tomas.galia@osu.cz RNDr. Václav ŠKARPICH, Ph.D., email: vaclav.skarpich@osu.cz Department of Physical Geography and Geoecology, Faculty of Science, University of Ostrava Chittussiho 10, 71000 Ostrava-Slezská Ostrava, Czech Republic

Initial submission 8 February 2013, final acceptance 2 July 2013

Please cite this article as:

GALIA, T., ŠKARPICH, V. (2013): Coarse bed sediments in a headwater channel as indicators of fluvial processes and slope-channer coupling: A case study from the Carpathian Mountains (Czech Republic). Moravian Geographical Reports, Vol. 21, No. 3, p. 2-11. DOI: 10.2478/mgr-2013-0012. 